\title{
The use of Postponement Decisions in Determining Supply Chain Strategies of Light Vehicle
} Manufacturers in South Africa

\author{
Intaher Marcus Ambe \\ School of Public and Operations Management, University of South Africa, South Africa \\ ambeim@unisa.ac.za
}

\begin{abstract}
This article investigates the use of postponement decisions in determining the supply chain strategies of light vehicle manufacturers in South Africa. The article is exploratory and descriptive in nature. A survey was conducted among light vehicle manufacturers and the findings analysed by means of descriptive statistics. The results revealed that postponement decisions could be used to determine the supply chain architecture used by light vehicle manufacturers in South Africa. With regard to postponement decisions, the study found that all the light vehicle manufacturers made use of a lean supply chain strategy, while a few made use of an agile supply chain strategy. The results also revealed that all the production lines engaged in full speculation based on projected forecasting, and therefore employed a lean supply chain strategy. In terms of the postponement decisions made in line with the parent company of origin, European manufacturers 1 and 2 kept a work-in-progress inventory of stock to be customised for a particular customer. These manufacturers thus employed a lean and agile supply chain strategy, while most of the manufacturers adopted a lean supply chain strategy. All the manufacturers, except Asian manufacturer 1 and the American manufacturer, employed both lean and agile supply chain strategies. Therefore, the majority of the light vehicle manufacturers employed lean supply chain strategies in their inbound and outbound supply chain, while a few employed an agile supply chain strategy in their outbound supply chain, there by indicating leaglity. The article provides evidence of some form of postponement practice being followed by light vehicle manufacturers.
\end{abstract}

Keywords: Postponement, supply chain, decisions, strategies, automotive environment

\section{Introduction}

Postponement is one of the most popular and widely used concepts in contemporary supply chains. Postponement, generally known as late customisation or delayed product differentiation, involves delaying supply chain activities purposefully until the customer order is known. Postponement centres around delaying activities in the supply chain until real information about the markets is available. The viability of postponement is determined by the structure of the supply chain characteristics (Battezzati \& Magnani, 2000). A postponement strategy brings benefits to an enterprise, such as a reduced inventory, pooling risk, and accurate forecasts. However, the postponement is not suitable for all situations, and there is a wide range of delay, determined by the appropriateness of the location of the materials' decoupling point, which is reflected in the most popular classification of manufacturing types (Zheng \& Mesghouni, 2011). Therefore, moving one or more activities forward through postponement increases the agility of the supply chain.

One of the most important links in supply chains is manufacturers who have developed many supply chain strategies to address the problems of product proliferation and meeting customers' exact needs. Huang and Li (2009:363) asserted that postponement has been identified as one of the important characteristics of modern and competitive supply chains, and the implementation of postponement decisions may require significant reconfiguration of the supply chain. According to Feitzinger and Lee (1997), postponement has been increasingly used as an important supply chain decision. However, the choice of a supply chain strategy is intimately related to the positioning of the decoupling point (Wikner \& Rudberg, 2005:624). Postponement is used to move the decoupling point closer to the end user and increase the efficiency and effectiveness of the supply chain (Yang \& Burns, 2003:2078). Having postponement in the supply chain allows suppliers to adjust their production schedules and plan ahead for the components that are needed for production. Therefore, postponement partially mediates the relationship in supply chain strategies (Gunasekaran et al., 2008). There are several factors that should be taken into account in determining supply chain strategies, such as product characteristics (Mason-Jones, Naylor \& Towill, 2000; Christopher, 2005), manufacturing techniques (Hull, 2005), decision drivers of the supply chain, as well as postponement characteristics (Vinodh, Sundararaj \& Devadasan, 2009). 
Despite the well-known importance of postponement as a strategic supply chain decision tool, it has not been empirically used to determine supply chain strategies in developing economies (Chaudhry, 2010; Yang et al., 2005; Boone et al., 2007; Yeung et al., 2007). Most of the studies on postponement are based in Western and highly developed countries (Qi, Boyer and Zhao, 2009:668; Huang \& Li, 2009:363). While these studies have opened up debate and discussion on postponement decisions, generating new insights into how it could be used in different supply chain strategies, there remains a need to provide empirical evidence in the context of South Africa. This article extends studies on the application of postponement decisions within the supply chain environment. It investigates the use of postponement decisions in determining supply chain strategies of light vehicle manufacturers in South Africa. The remainder of the article presents a conceptual review of the relevant literature, the research methodology used, as well as the findings and discussion, followed by the conclusion.

\section{Literature Review}

This section presents a review of the literature on supply chain strategies, as well as postponement decisions in supply chains.

Supply chain strategies: Supply chain strategy utilises inter-firm coordination to facilitate the achievement of objectives focused on revenue growth, operating cost reduction, working capital and fixed capital efficiency, in order to maximise shareholder value (Hallgren \& Olhager, 2009). Fisher (1997) developed a model that helps managers to understand the nature of their product, and to devise a supply chain strategy that can best satisfy the specific demands (Jacobs, Chase \& Aquilano, 2009:362). However, there are several factors (some of which were mentioned above) that should be taken into account when determining supply chain strategies, such as product characteristics (Mason-Jones, Naylor \& Towill, 2000; Christopher, 2005); manufacturing techniques (Hull, 2005); decision drivers of supply chains; and postponement characteristics (Vinodh, Sundararaj \& Devadasan, 2009). There are two generic strategies in supply chain management (Hallgren \& Olhager, 2009). These strategies include "leanness" and "agility". Identifying the types of supply chain strategies (lean or agile) may be appropriate in different circumstances, in order to position the product in an organisation's portfolio according to its supply and demand characteristics.

Supply chain scholars have indicated that lean and agility approaches can be integrated in a variety of ways (Faisal, Banwet \& Shankar, 2006:884). This is because they complement one another, and can be combined to create a new manufacturing paradigm under the name leagile (Vinodh et al., 2009: 573). Krishnamurthy and Yauch (2007: 591) define leagility as "a system in which the advantages of leanness and agility are combined". The aim of leagile supply chains is to infuse competitiveness into an organisation in a cost-effective manner. In the leagile supply chain paradigm, lean and agile approaches are combined within a total supply chain strategy, by positioning the decoupling point (DP) in order to best suit the need for responding to a volatile demand downstream, while providing level scheduling upstream from the DP. Postponement is used to move the DP closer to the end user and increase the efficiency and effectiveness of the supply chain (Yang \& Burns, 2003:2078).

The decoupling point: The decoupling point is the most cited of the three hybrid strategies (Wikner \& Rudberg, 2005). It separates the lean and agile paradigms. According to Hull (2005:230), this is the point where the product characteristics, based on which customers place their orders, penetrate (Rahiminia et al., 2009:802). It is the point where the order-driven and forecastable meet. Krishnamurthy and Yauch (2007:592) assert that lean and agile systems do not co-exist, but have a demarcation between them. Figure 1below illustrates the decoupling point of the lean and agile paradigms. The decoupling point approach employs the concept of postponement, which is now increasingly and more widely used by organisations in a range of industries (Hull, 2005; Wikner \& Rudberg, 2005). The concept of postponement dates back to 1920. It can be defined as "the delaying of operational activities in a system until customer orders are received rather than completing activities in advance and then waiting for orders" (Krishnamurthy \& Yauch, 2007:592). The basic idea is to hold inventory in some generic or modular form, and only complete the final assembly or configuration when the precise customer order is received (Christopher, 2005:120). A company may delay the forward movement (distribution) of products as long as possible in the chain of operations, keeping these product(s) in storage at central locations in the distribution chain (Hilletofth, 2009:22). This 
can be done through assembly (assembly-to-order), production (make-to-order) and sourcing, or even design (engineer-to-order).

\section{Figure 1: The decoupling point}

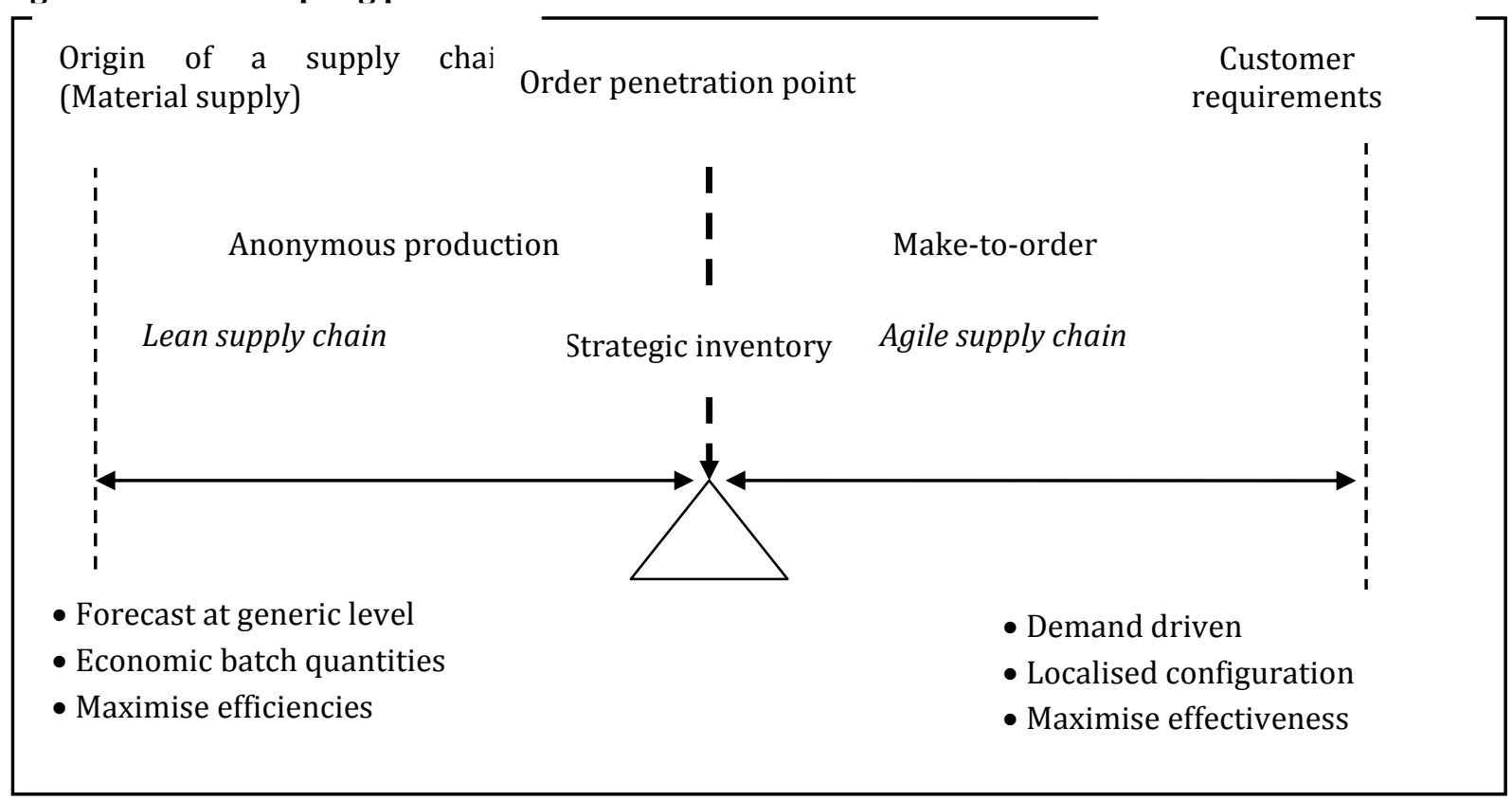

Source: Adapted from Christopher (2005:121)

Thus, the choice of a supply chain strategy is intimately related to the positioning of the decoupling point (Wikner \& Rudberg, 2005:624). The types of manufacturing strategies in which to place the decoupling point in order to determine supply chain paradigms have been well documented. The four most common manufacturing activities based on speculation and customer order commitments are make-to-stock, make-toorder, configure-to-order and engineer-to-order (Taylor, 2004:28; Cohen \& Rousell, 2005:12; Webster, 2008:218; Bowersox et al., 2010:87).Therefore, the determination of postponement strategies is based on identifying four representative supply chains that are appropriate for different manufacturing environments (Bowersox, Closs \& Cooper, 2010:87). These include make-to-stock (MTS); assemble-to-order (ATO); configure-to-order (CTO); make-to-order (MTO); design-to-order (DTO); and engineer-to-order (ETO). In a MTS supply chain, the end consumer has no individual inputs in the configuration of the product, and typically purchases the product 'as is' from a retailer. The supply chains are extremely common, because they are appropriate for high-volume, low-profit margin, commodity products (Jonsson, 2008:153; Stavrulaki \& Davis, 2010:134). In a CTO, customers have a limited number of choices in the configuration of the final product (Jonsson, 2008:153). The MTO supply chain affords consumers the opportunity to have at least some part of the product uniquely built into their individual specifications (Stavrulaki \& Davis, 2010:138). Products made with the ETO supply chain represent the ultimate in customisation, because there are virtually no constraints on customers with respect to incorporating their individual preferences and requirements into the final design of the product. Therefore, products from an ETO supply chain are by definition low volume (often volumes of one), with highly variable characteristics, as well as high prices. Table 1 below shows that there are characteristics of postponement decisions in supply chains.

Postponement as a Supply Chain Strategy: Postponement refers to a concept whereby activities in the supply chain are delayed until a demand is realised (Boone, Craighead \& Hanna, 2007:594). This involves intentionally delaying the execution of a task, instead of starting it with incomplete or unreliable information inputs (Yeung, Selen, Deming \& Min, 2007:332). Therefore, postponement, or 'delayed configuration' as it is called, is based on the principle of seeking to design products by using common platforms, components or modules, but postponing the final assembly or customisation until the precise market destination or customer requirement is known (Christopher, 2003:288, 289). Basically, postponement encompasses holding 
inventory in a generic form, in the fewest locations, and only completing or finally configuring the product once real demand is known (Christopher, 2003:286). As indicated by Taylor (2004), postponement is used to manage uncertainties, and the final operations that result in a customised product for the end customer are performed when the uncertainty is removed (Waters, 2007:206). It allows organisations to be flexible in developing different versions of a product as needed. It has the potential to improve responsiveness while reducing costs, such as inventory, transport, storage and obsolescence costs (Boone et al., 2007:594).

Table 1: Manufacturing characteristics in supply chains

\begin{tabular}{|c|c|c|}
\hline $\begin{array}{l}\text { Postponement } \\
\text { characteristics }\end{array}$ & Lean supply chain & Agile supply chain \\
\hline Manufacturing strategies & MTS & СTO, MTO, ЕTO \\
\hline Manufacturing cost & Low cost manufacturing strategy & Cost is demand-driven (flexibility) \\
\hline Inventory holding & $\begin{array}{l}\text { Minimum inventory in the } \\
\text { production process }\end{array}$ & $\begin{array}{l}\text { Hold inventory based on demand } \\
\text { specifications (pull by orders) }\end{array}$ \\
\hline Changes in manufacturing & $\begin{array}{l}\text { Little or no changes (based on } \\
\text { projected forecasting) }\end{array}$ & $\begin{array}{l}\text { Make provision for changes in } \\
\text { customer demand }\end{array}$ \\
\hline Manufacturing process & Push supply & Pull supply \\
\hline
\end{tabular}

Postponement is an excellent example of a push-pull strategy (Simchi-Levi, Kaminsky \& Simchi-Levi, 2008:190). Before end customer demand is known, a push-based strategy is used to produce generic products based on a forecast. The demand for generic products is an aggregation of demand for all the organisation's corresponding end products, hence forecasts are more accurate. By contrast, customer demand for a specific end product typically has a high level of uncertainty, and product differentiation therefore occurs only in response to individual demand. The portion of the supply chain starting from the time of differentiation is pull-based (Simchi-Levi et al., 2008:191). Earlier in this article, the decoupling point was defined as the point at which real demand penetrates upstream in a supply chain (Christopher, 2003:28). From this, it can also be deduced that the push-pull boundary is the same point as the decoupling point. Postponement takes place at the decoupling point or the push-pull boundary, and the decoupling point determines the form in which inventories are held. Therefore, once the decoupling point is determined, organisations must support push-pull decisions to meet customers' expectations (Goldsby, Griffis and Roath, 2006:60).

The various forms of postponement include full postponement, assembly/logistics postponement, manufacturing postponement and full speculation. Full postponement refers to "making the decoupling point earlier in the process", which means that a few steps in the design process will be performed under conditions of uncertainty and forecasting (Świerczek, 2010:35). At the same time, it decreases the necessary stock of semi-finished goods. For this postponement strategy to be successful, processes have to be designed in such a manner that less differentiating steps can be performed prior to the decoupling point (Balland \& Lindholm, 2012:7). According to Yang, Burns and Backhouse (2004), assembly or logistics postponement refers to the movement of finished goods (It is also referred to as semi-finished goods (Gattorna, 1998), where the last differentiating stages are performed at the warehouse/distribution centre (DC). Gattorna (1998) refers to stages such as labelling, packaging and assembly. These delayed processes allow a product to be centrally stored and customised according to local market specificities when a customer order is received. Manufacturing processes are based on speculation and logistics processes are customer order-initiated (Balland \& Lindholm, 2012:8).

Manufacturing postponement focuses on designing products so that they are kept undifferentiated for as long as possible (Yang et al., 2004). This decreases inventory, since components can be used for multiple products. Relevant processes in this regard are labelling, packaging, assembly and manufacturing (Świerczek, 2010:35). The manufacturing process is redesigned in order to allow processes that do not differentiate the product and are based on forecasts to be completed prior to the customer order decoupling point (CODP). The processes that differentiate the product are placed after the CODP and are customer order-initiated. For instance, Benetton places the dying process of its clothes after the knitting process, thereby allowing for a more accurate demand of colours (Gattorna, 1998). The following three formalised approaches are used in 
manufacturing postponement: (1) standardisation; (2) modular design; and (3) process restructuring (Balland \& Lindholm, 2012:9).Full speculation is the opposite of postponement in any form (full, logistics or manufacturing). The full speculation strategy can, in one way, be compared to a MTS production strategy. In this strategy, all manufacturing operations are performed without the involvement of the customer (Balland \& Lindholm, 2012:7). The product is distributed in a decentralised way, often in large volumes. These large volumes allow for the use of economies of scale at several points in the supply chain (Świerczek, 2010:35). Table 2 below indicates the various forms of postponement.

Table 2: Types of postponement strategies

\begin{tabular}{ll}
\hline Types of postponement & Authors \\
\hline Full postponement & Lee (1998); Świerczek (2010); Balland \& Lindholm (2012). \\
Assembly/logistics postponement & Gattorna (1998); Yang et al. (2004); Balland \& Lindholm (2012). \\
Manufacturing postponement & Gattorna (1998); Yang et al. (2004); Świerczek (2010); Balland \& \\
& Lindholm (2012). \\
Full speculation & Balland \& Lindholm (2012); Świerczek (2010). \\
\hline
\end{tabular}

These four postponement strategies can be applicable to different phases of the supply chain, as indicated in Figure 2 (Świerczek, 2010:35). For example, make-to-stock (MTS) is typical of a full speculation strategy, configure-to-order (CTO) refers to assembly/logistics postponement, make-to-order (MTO) is linked to manufacturing postponement, and engineer-to-order (ETO) corresponds to full postponement.

Figure 2: Application of postponement strategies in the supply chain

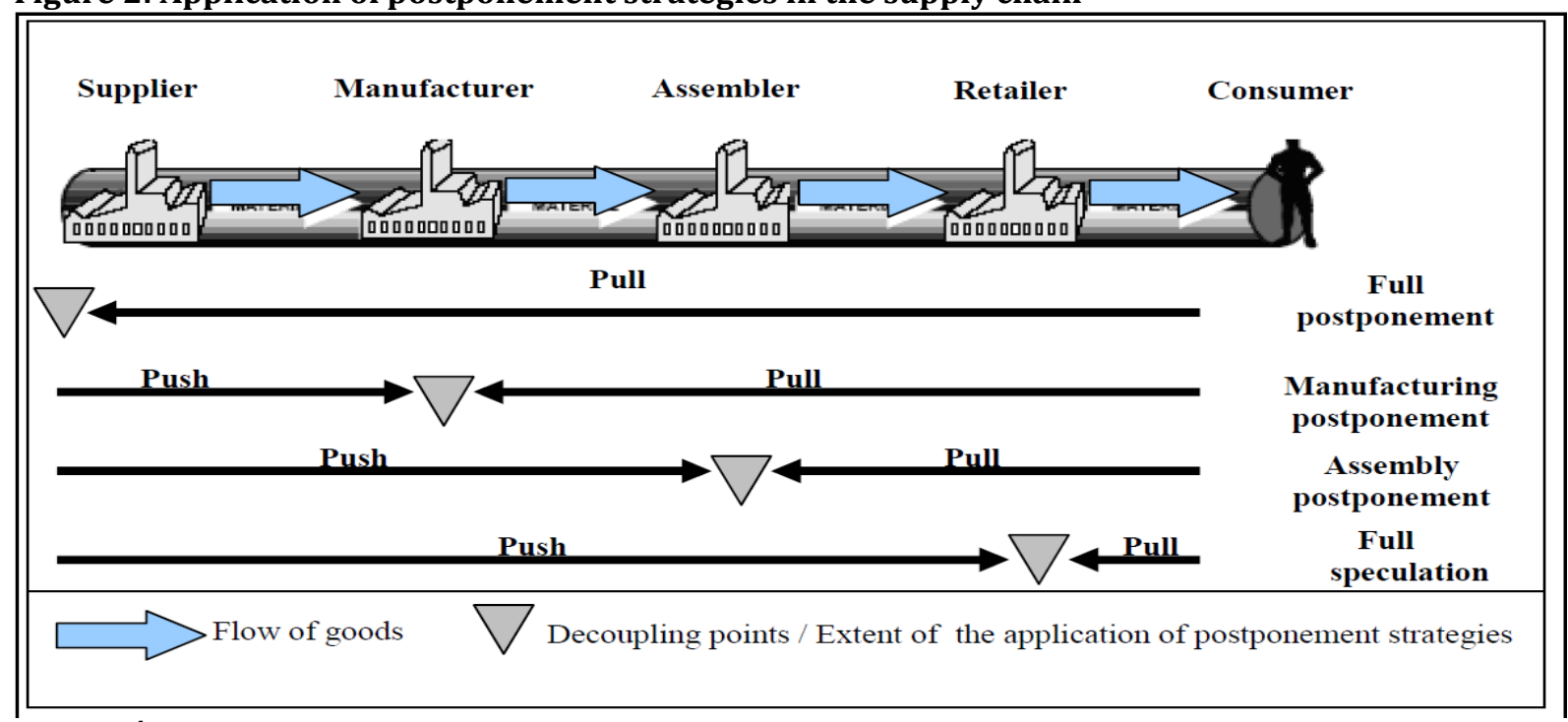

Source: Świerczek (2010:35); Balland \& Lindholm (2012:11)

These points indicate different degrees of application of postponement strategies in supply chains. Therefore, the location of the material decoupling point is often perceived as a primary tool to indicate the extent of the application of postponement strategies in supply chains. Postponement is an excellent example of a push-pull strategy (Simchi-Levi, Kaminsky \& Simchi-Levi, 2008:190).

\section{Methodology}

This study was exploratory and descriptive in nature, based on a survey of light vehicle manufacturers in South Africa. The target population was light vehicle manufacturers [original equipment manufacturers (OEMs)] in the South African automobile industry (total target population: 7 OEMs). The study made use of the total target population (all light vehicle manufacturers in South Africa), because the study sought to obtain an in-depth understanding of the implications of postponement decisions on supply chain strategies. In South Africa, the automotive industry is the leading industry in supply chain practices (Supply chain 
foresight, 2010). The industry is often referred to as a barometer for the health of the country's economy [7\% of GDP for 2012 (Automotive Industry Export Council [AIEC], 2013)]. Vehicle manufacturers face enormous supply chain challenges, which include the adoption of cost reduction measures and service improvement (Supply chain foresight, 2007). The majority of companies in the industry do not only operate with low levels of collaboration, but are also not very market-sensitive or reactive to the changing market (Supply Chain Intelligence Report [CSIR], 2009). Therefore, an efficient and responsive supply chain strategy is required for South African automotive industry manufacturers who assemble different types of vehicles for local and international markets, in order to produce at a competitive cost and respond quickly and reliably to firstworld market demands.

South Africa houses major international assemblers and manufacturers, including OEMs, from traditional manufacturing powerhouses in the USA, Japan and Europe, where key decisions about their manufacturing are made. Most of the global motor vehicle brand manufacturers are represented in South Africa. These include Toyota, BMW, Volkswagen, DaimlerChrysler, Nissan, General Motors, Ford (incorporating Mazda, Land Rover and Volvo) and Fiat. Some of the OEMs manufacture certain models locally for the local market, as well as exporting some of their production outputs. The South African automotive industry produces two broad categories of vehicles, namely passenger vehicles and commercial vehicles. Passenger vehicles are classified as A to D class, premium and SUVs, while commercial vehicles are classified as light commercial, medium commercial and heavy commercial. Passenger vehicles and light commercial vehicles are referred to as light vehicles.

One manufacturer may have various production lines, with different supply chain strategies for each. This is because supply chain strategies are unique to a production line and not the supply chain in general, as indicated by Fisher (1997). This study focused on one production line (models) for each of the manufacturers. In this regard, postponement decisions along the product line, manufacturing and decision drivers were investigated. The population for the study therefore constituted light vehicle manufacturers (passenger and light commercial vehicles), which were chosen, firstly, because this would incorporate all the automotive manufacturers in South Africa. Secondly, both categories of vehicle are used for personal purposes and therefore require distinctive features and characteristics.Purposive sampling was used in this study, with a focus on supply chain experts with competent knowledge of the supply chain processes in their organizations (senior supply chain managers). The basic criteria for selecting the respondents were, firstly, that the company was a local manufacturer of light vehicles in South Africa, and secondly, that the respondent was an employee in a senior SCM position in that company. In some companies, more than one respondent had to participate in the interview process, in order to complete the different parts of the interview questionnaire.

A total of twelve $(\mathrm{N}=12)$ in-depth interviews were conducted with six of the seven light vehicle manufacturers in South Africa. A semi-structured interview questionnaire was used to elicit the opinions of the respondents. The interviews were conducted at different manufacturers for a particular locally manufactured car (model). As indicated by Fisher (1997), a supply chain strategy is dependent not on a supply chain, but on a product (or in this case a model). Therefore, in this study, the interviewees who were senior supply chain managers had to identify a locally manufactured model (production line) on which the interview would be based. In this article, only the structured responses were analysed. The constructs in the structured questions were measured using a five-point Likert-type scale, where (1) is "strongly disagree" and (5) is "strongly agree". The data was analysed descriptively using the Statistical Package for Social Sciences (SPSS). Descriptive statistics were used to describe the main features of the data in quantitative terms (Gray, Williamson, Dalphin, 2007:44), and the results were presented in the form of mean value scores.

\section{Findings and Discussion}

This section of the article discusses the results of the study. As indicated in the literature review, supply chain strategies are based on a particular locally manufactured vehicle model or production line. The findings relating to strategies based on postponement decisions are interpreted for a particular model, and are not necessarily applicable to other models manufactured by the same company. The results of the study are firstly discussed based on the responses in relation to the postponement characteristics of the product as a 
whole, and thereafter according to the various manufacturers. In addition, the findings are mapped to determine the alignment of postponement decisions to supply chain strategies.

Responses regarding postponement characteristics of the product: Statements relating to postponement were used to establish the relationship between manufacturing characteristics and supply chain strategies. A postponement strategy shows the position (decision point) where a strategy changes from one to another (from a lean to an agile supply chain). The respondents were asked to indicate their level of agreement with regard to the application of postponement by means of six statements, using a five-point Likert scale ranging from 1 (strongly disagree) to 5 (strongly agree). For purposes of analysis, the following abbreviations were used: $S D$ for strongly disagree; $D$ for disagree; $N$ for neither agree nor disagree; $A$ for agree; and $S A$ for strongly disagree. Table 1 below indicates the frequency distribution (in \%) per statement.

Table 1: Responses regarding postponement characteristics

\begin{tabular}{|c|c|c|c|c|c|}
\hline \multirow[t]{2}{*}{ Statements } & \multicolumn{5}{|c|}{ Percentage } \\
\hline & SD & D & $\mathbf{N}$ & $\mathbf{A}$ & SA \\
\hline $\begin{array}{l}\text { Our strategic suppliers keep inventory in the form } \\
\text { of modules, components and materials }\end{array}$ & $0.0 \%$ & $0.0 \%$ & $0.0 \%$ & $83.3 \%$ & $16.7 \%$ \\
\hline $\begin{array}{l}\text { We keep fully assembled vehicles in stock } \\
\text { (assembled vehicles) }\end{array}$ & $8.3 \%$ & $0.0 \%$ & $8.3 \%$ & $75.0 \%$ & $8.3 \%$ \\
\hline Our dealers keep fully assembled vehicles in stock & $0.0 \%$ & $0.0 \%$ & $0.0 \%$ & $66.7 \%$ & $33.3 \%$ \\
\hline $\begin{array}{l}\text { We keep work-in-progress inventory to be } \\
\text { customised for specific customer orders }\end{array}$ & $16.7 \%$ & $41.7 \%$ & $16.7 \%$ & $25.0 \%$ & $0.0 \%$ \\
\hline $\begin{array}{l}\text { We only order modules, components and materials } \\
\text { from our strategic suppliers when the customer } \\
\text { specifications are known }\end{array}$ & $16.7 \%$ & $8.3 \%$ & $0.0 \%$ & $50.0 \%$ & $25.0 \%$ \\
\hline $\begin{array}{l}\text { We make provision for the finalisation of some } \\
\text { features to our vehicles at the dealership, based on } \\
\text { final customer requests }\end{array}$ & $33.3 \%$ & $0.0 \%$ & $8.3 \%$ & $8.3 \%$ & $50.0 \%$ \\
\hline
\end{tabular}

Table 1 reveals that all the respondents (100\%) agreed that their strategic suppliers kept inventory in the form of modules, components and materials. Furthermore, the majority of the respondents (83.3\%) agreed that fully assembled models of the vehicles were kept in stock. All the respondents $(100.0 \%)$ agreed that their strategic customers (dealers) kept fully assembled vehicles in stock. More than half (58.4\%) of the respondents disagreed that they kept work-in-progress inventory to be customised for specific customer orders, while only a quarter $(25.0 \%)$ agreed. Three-quarters of the respondents $(75.0 \%)$ agreed that modules, components and materials were only ordered from strategic suppliers when the customer specifications were known. More than half (58.3\%) of the respondents agreed that they made provision for the finalisation of some features to their vehicles at the dealership based on final customer requests, while a third (33.3\%) strongly disagreed. It is thus clear that strategic suppliers keep inventory in the form of modules, components and materials, and most manufacturers keep fully assembled vehicles in stock $83.3 \%$ agreement). Work-in-progress inventory is kept by most manufacturers, which indicates that a decision about final assembly is made at the manufacturer (decoupling point) based on final customer requirements. This implies the use of a lean and agile (leagile) supply chain strategy. Overall, the findings suggest that the majority of the respondents used some form of postponement, which indicates an element of agility, hence the use of a leagile supply chain. 
Table 2: Responses regarding postponements by manufacturers

\begin{tabular}{|c|c|c|c|c|c|c|}
\hline \multirow[t]{2}{*}{ Statements } & \multicolumn{6}{|c|}{ Mean level of agreement } \\
\hline & E1 & AM & E2 & A1 & A2 & E3 \\
\hline $\begin{array}{l}\text { Our strategic suppliers keep inventory in the form } \\
\text { of modules, components and materials }\end{array}$ & 4.00 & 4.50 & 4.00 & 4.00 & 4.00 & 4.50 \\
\hline $\begin{array}{l}\text { We keep fully assembled vehicles in stock } \\
\text { (assembled vehicles) }\end{array}$ & 2.50 & 4.50 & 4.00 & 3.75 & 4.00 & 4.00 \\
\hline Our dealers keep fully assembled vehicles in stock & 4.50 & 4.50 & 4.00 & 4.25 & 5.00 & 4.00 \\
\hline $\begin{array}{l}\text { We keep work-in-progress inventory to be } \\
\text { customised for specific customer orders }\end{array}$ & 3.50 & 1.50 & 4.00 & 2.75 & 1.00 & 2.00 \\
\hline $\begin{array}{l}\text { We only order modules, components and materials } \\
\text { from our strategic suppliers when the customer } \\
\text { specifications are known }\end{array}$ & 4.50 & 3.00 & 4.00 & 2.75 & 4.00 & 4.50 \\
\hline $\begin{array}{l}\text { We add some features to our vehicles at the } \\
\text { dealership, based on final customer requests }\end{array}$ & 1.00 & 3.00 & 5.00 & 4.25 & 5.00 & 3.00 \\
\hline
\end{tabular}

Postponement decisions by manufacturers: To gain a further understanding of how different manufacturers apply postponement practices, the responses were analysed according to the mean level of agreement per manufacturer. Table 2 below presents the responses in this regard. For purposes of analysis, the following abbreviations were used: $E 1$ for European manufacturer 1; E2 for European manufacturer 2; E3 for European manufacturer 3; $A M$ for American manufacturer; $A 1$ for Asian manufacturer 1; and $A 2$ for Asian manufacturer 2. As indicated in Table 2, all the manufacturers, in general, agreed that their strategic suppliers kept inventory in the form of modules, components and material (means of 4.00 to 4.50). European manufacturers 2 and 3, Asian manufacturer 2 and the American manufacturer agreed that they kept fully assembled vehicles in stock (assembled vehicles) (means of 4.00 to 4.50), while European manufacturer 1 disagreed (a mean of 2.50). All the manufacturers agreed that their dealers kept fully assembled vehicles in stock, thereby indicating a lean supply chain. European manufacturers 1 and 2 were the only manufacturers that kept work-in-progress inventory to be customised for specific customer orders (means of 3.50 and 4.00 respectively), while the other manufacturers disagreed in this regard (means of 1.00 to 2.75). Only the American manufacturer disagreed that it only ordered modules, components and materials from its strategic suppliers when the customer specifications were known (a mean of 2.75), while four of the other five manufacturers agreed (means of 4.00 to 4.50). Three of the manufacturers (European manufacturer 2, Asian manufacturers 1 and 2) agreed that they made provision for additional features for vehicles at the dealership based on customer requests (means of 4.25 to 5.00), while European manufacturer 1 disagreed in this regard (a mean of 1.00).

The results show that European manufacturer 1 did not keep fully assembled vehicles in stock, thereby indicating a MTO strategy (agile supply chain). Only European manufacturers 1 and 2 tended to keep workin-progress inventory, which indicates the point where a lean supply chain changes to an agile supply chain. The results provide evidence of some form of postponement practice being adopted by the manufacturers. Therefore, although some supply chains were mainly lean, they may have applied some agile elements at different points in the supply chain. However, to determine the exact positions (side of the supply chain) of lean and agile (or leagile) supply chain strategies, the concept of postponement needs to be employed. In the leagile supply chain paradigm, lean and agile are combined within a total supply chain strategy, by positioning the decoupling point (DP) in order to best suit the need for responding to a volatile demand downstream, while providing level scheduling upstream from the DP. Postponement is used to move the DP closer to the end user and increase the efficiency and effectiveness of the supply chain. To determine the supply chain strategy on different sides of the supply chain for each of the models (production lines), the study also sought responses to questions relating to postponement. The four forms of postponement are full postponement (CTO), manufacturing postponement (MTO) and assembly postponement (ETO), which are all associated with an agile supply chain strategy; and full speculation (MTS), which is associated with a lean supply chain strategy. 
The results relating to postponement revealed that, for all manufacturers, their strategic suppliers kept inventory in the form of modules, components and materials (100.0\%). In addition, fully assembled vehicles were kept in stock by the majority (83.3\%) and with their dealers by all respondents $(100.0 \%)$. This shows that all the production lines engaged in full speculation based on projected forecasting, and therefore at least employed a lean supply chain strategy. European manufacturers 1 and 2 agreed that they kept work-inprogress inventory in stock to be customised for a particular customer, thereby indicating the decisionmaking or decoupling point (means of 3.50 and 4.00 respectively). These manufacturers thus employed a lean and agile supply chain strategy (leagile supply chain strategy), while most of the manufacturers followed a lean supply chain strategy. In general, all the manufacturers, except Asian manufacturer 1 and the American manufacturer (means of 2.75 and 3.00), agreed that modules, components and materials were only ordered when the customer specifications were known, which means that both lean and agile supply chains should be employed. European manufacturer 1 did not add some features to the vehicle at the dealership, based on customer requests (mean of 1.00), while European manufacturer 2 did this (mean of 5.00). The results indicate that, based on the postponement characteristics, both lean and agile (leagile) supply chain strategies should be implemented.

To determine the position in the supply chain where inventory is held (postponement exists) for each of the models, two characteristics, namely holding WIP inventory (MTO), and adding some features at the dealership, based on customer requests, were used, as they depict different postponement points in the supply chain. Table 3below shows the alignment of postponement characteristics to supply chain strategies. For purposes of analysis, the following abbreviations were used: E1 for European manufacturer 1; E2 for European manufacturer 2; E3 for European manufacturer 3; AM for American manufacturer; A1 for Asian manufacturer 1 ; and A2 for Asian manufacturer 2.

Table 3: Aligning postponement decisions to supply chain strategy

\begin{tabular}{|c|c|c|c|c|}
\hline $\begin{array}{l}\text { Light } \\
\text { Vehicle }\end{array}$ & Postponement characteristics & Mean & $\begin{array}{l}\text { Forms of } \\
\text { postponement based } \\
\text { on manufacturing } \\
\text { characteristics }\end{array}$ & $\begin{array}{l}\text { Supply chain } \\
\text { strategy based } \\
\text { on forms of } \\
\text { postponement }\end{array}$ \\
\hline \multirow[t]{2}{*}{ E1 } & $\begin{array}{l}\text { WIP is kept to be customised for specific } \\
\text { orders }\end{array}$ & 3.50 & $\begin{array}{l}\text { Manufacturing } \\
\text { postponement }\end{array}$ & Agile supply chain \\
\hline & $\begin{array}{l}\text { Some features are added to the vehicle at the } \\
\text { dealership based on the final customer } \\
\text { request }\end{array}$ & 1.00 & Full speculation & Lean supply chain \\
\hline \multirow[t]{2}{*}{$\mathrm{AM}$} & $\begin{array}{l}\text { WIP is kept to be customised for specific } \\
\text { orders }\end{array}$ & 1.50 & Full speculation & Lean supply chain \\
\hline & $\begin{array}{l}\text { Some features are added to the vehicle at the } \\
\text { dealership based on the final customer } \\
\text { request }\end{array}$ & 3.00 & Full speculation & Lean supply chain \\
\hline \multirow[t]{2}{*}{ E2 } & $\begin{array}{l}\text { WIP is kept to be customised for specific } \\
\text { orders }\end{array}$ & 4.00 & $\begin{array}{l}\text { Manufacturing } \\
\text { postponement }\end{array}$ & Agile supply chain \\
\hline & $\begin{array}{l}\text { Some features are added to the vehicle at the } \\
\text { dealership based on the final customer } \\
\text { request }\end{array}$ & 5.00 & Full speculation & Lean supply chain \\
\hline \multirow[t]{2}{*}{ A1 } & $\begin{array}{l}\text { WIP is kept to be customised for specific } \\
\text { orders }\end{array}$ & 2.75 & Full speculation & Lean supply chain \\
\hline & $\begin{array}{l}\text { Some features are added to the vehicle at the } \\
\text { dealership based on final customer request }\end{array}$ & 4.25 & Full speculation & Lean supply chain \\
\hline \multirow[t]{2}{*}{ A2 } & $\begin{array}{l}\text { WIP is kept to be customised for specific } \\
\text { orders }\end{array}$ & 1.00 & Full speculation & Lean supply chain \\
\hline & $\begin{array}{l}\text { Some features are added to the vehicle at the } \\
\text { dealership based on the final customer } \\
\text { request }\end{array}$ & 5.00 & Full speculation & Lean supply chain \\
\hline \multirow[t]{2}{*}{ E3 } & $\begin{array}{l}\text { WIP is kept to be customised for specific } \\
\text { orders }\end{array}$ & 2.00 & Full speculation & Lean supply chain \\
\hline & $\begin{array}{l}\text { Some features are added to the vehicle at the } \\
\text { dealership based on the final customer } \\
\text { request }\end{array}$ & 3.00 & Full speculation & Lean supply chain \\
\hline
\end{tabular}


As indicated in Table 3, the form of postponement for each model was determined from the characteristics and their mean scores. Thereafter, the supply chain strategy was identified based on the forms of postponement. It is clear from Table 3 that most of the models had the full speculative form of postponement, thereby indicating a lean supply chain strategy. On the other hand, European manufacturers 1 and 2 had manufacturing postponement, thereby indicating a leagile supply chain strategy. To further determine whether their responses were in line with practices, a portfolio matrix was developed. Figure 1below presents the portfolio matrix for postponement.

Figure 1: Portfolio matrix for postponement

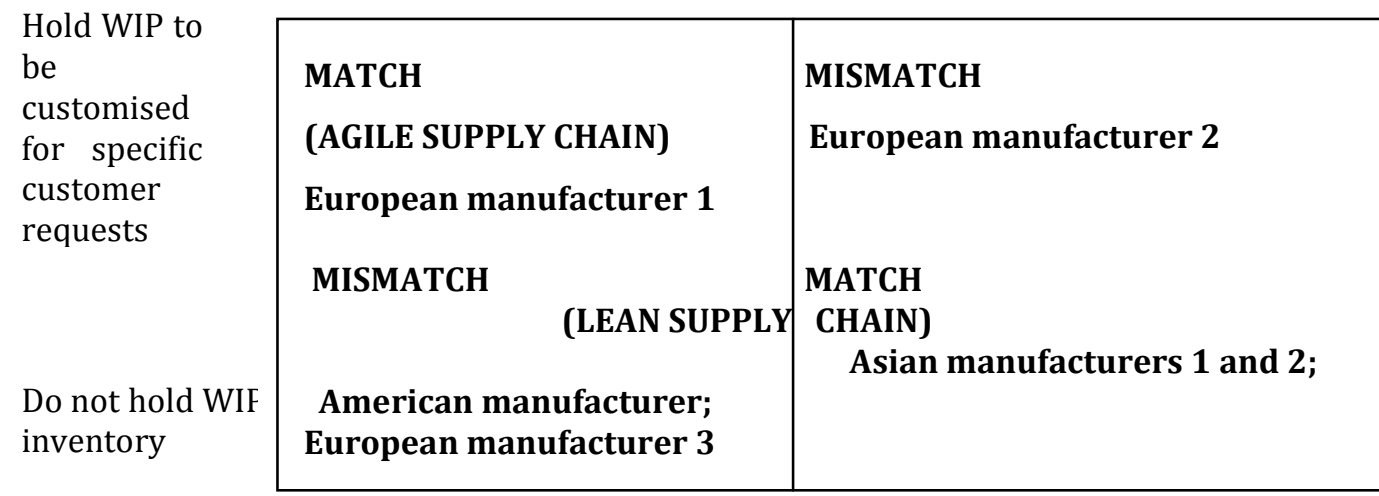

No provision made for features to be added

Provision made for features to be added at at dealership based on customer requests dealership based on customer requests

If the WIP inventory has been customized at the time of manufacturing, there is little or no chance of features being added to the model, because it was done based on the customer's request. As indicated in Figure 1, all the manufacturers were correctly positioned, except for European manufacturer 2.This indicates that they kept WIP inventory to be customized for specific customer needs, and that some features were added at the dealership, based on customers' requests.

\section{Conclusion}

The purpose of this article was to determine the supply chain strategies of light vehicle manufacturers in South Africa based on postponement decisions. There are four major forms of postponement: full postponement (CTO); manufacturing postponement (MTO); assembly postponement (ETO), which are all associated with an agile supply chain strategy; and full speculation (MTS), which is associated with a lean supply chain strategy. Postponement decisions can be used to determine the exact positions (side of the supply chain) of lean and agile (or leagile) supply chain strategies through the decoupling point. Based on a survey of light vehicle manufacturers in South Africa, it is clear that strategic suppliers keep inventory in the form of modules, components and materials, and that most manufacturers keep fully assembled vehicles in stock. Overall, the findings suggest that the majority of light vehicle manufacturers used some form of postponement, which indicates an element of agility, hence the use of a leagile supply chain. The results also show that all the production lines engaged in full speculation based on projected forecasting, and therefore at least employed a lean supply chain strategy.

With regard to the specific light vehicle manufacturers used in this study, European manufacturers 1 and 2 kept work-in-progress inventory in stock to be customised for a particular customer (indicating the decisionmaking point or decoupling point). These manufacturers thus employed a lean and agile supply chain strategy (leagile supply chain strategy), while most of the manufacturers followed a lean supply chain strategy. All the manufacturers, except Asian manufacturer 1 and the American manufacturer, employed both lean and agile supply chain strategies. The article further suggests that if work-in-progress inventory has been customized at the time of manufacturing, there is little or no chance for features to be added to a model, as it was done 
based on customers' requests, hence using a lean supply chain strategy.Based on the findings, it is therefore evident that postponement decisions drive the implementation of a supply chain strategy.

\section{References}

Balland, J. \& Lindholm, S. (2012). Choosing the right postponement strategy: a focus on e-commerce and postponement. Master's thesis. Sweden: Jonkoping International Business School.

Battezzati, L. \& Magnani, R. (2000). Supply chains for FMCG and industrial products in Italy practices and the advantages of postponement. International Journal of Physical Distribution \& Logistics Management, 30(5), 413.

Boone, C. A., Craighead, C. W. \& Hanna, J. B. (2007). Postponement: An evolving supply chain concept. International Journal of Physical Distribution \& Logistics Management, 37(8), 594-611.

Bowersox, D. J., Closs, D. J. \& Cooper, M. B. (2010). Supply chain logistics management. $3^{\text {rd }}$ edition, Singapore: McGraw-Hill.

Byrnes, J. (2005). The age of precision markets. The Harvard Business School Working Knowledge Newsletter, April $2005 . \quad$ Available at: http://hbsworkingknowledge.hbs.edu/item.jhtml?id=4741\&t=dispatch(Accessed on 25November 2015)

Chaudhry, H. R. (2010). Postponement and Supply Chain Structure. Doctoral thesis. Raleigh, North Carolina: North Carolina State University.

Christopher, M. (2005). Logistics and supply chain management: Creating value-added networks, Harlow, England: Prentice Hall.

Christopher, M. (2003). Creating agile supply chains, in Gower handbook of supply chain management, edited by JL Gattorna. Burlington, VT: Gower: 283-295.

Cohen, S. \& Rousell, J. (2005). Strategic Supply Chain Management: The Five Disciplines for Top Performance. New York: McGraw-Hill.

Faisal, M. N., Banwet, D. K. \& Shankar, R. (2006). Mapping supply chains on risk and customer sensitivity dimensions, Industrial management and data systems, 106(6), 878-895.

Feitzinger, E. \& Lee, H. L. (1997). Mass customization at Hewlett-Packard: the power of postponement. Harvard Business Review, 3, 116-121.

Fisher, M. L. (1997). What is the Right Supply Chain for your Product? Harvard Business Review, 4, 105-116.

Gattorna, J. (1998). Strategic supply chain alignment. Aldershot: Gower.

Gray, P. S., Williamson, J. B., Karp, D. A. \& Dalphin, J. R. (2007). The research imagination: an introduction to qualitative and quantitative methods. New York: Cambridge.

Goldsby, T. J., Griffis, S. E. \& Roath, A. S. (2006), Modeling lean, agile, and leagile supply chain strategies. Journal of Business Logistics, 27(1).

Gunasekaran, A., Lai, K. H. \& Cheng, T. C. E. (2008). Responsive supply chain: competitive strategy in a networked economy, The International Journal of Management Science, 36, 549-564.

Hallgren, M. \& Olhager, J. (2009). Lean and agile manufacturing: external and internal drivers and performance outcomes. International Journal of Operations and Production Management, 29 (10), 976-999.

Hilletofth, P. (2009). How to develop a differentiated supply chain strategy. Industrial management and data systems, 109 (1), 16-33.

Huang, Y. Y. \& Li, S. J. (2009). The Current Status and Affecting Factors of Postponement Application in Greater China. Asia Pacific Management Review, 14(3), 363-378.

Hull, B. Z. (2005). Are supply (driven) chains forgetting? The International Journal of Logistics Management, 16(2), 218-236.

Jonsson, P. (2008). Logistics and supply chain management. London: McGraw-Hill.

Jacobs, F. R., Chase, R. B. \& Aquilano, N. J. (2009). Operations and supply management. $12^{\text {th }}$ edition. United States: McGraw-Hill.

Krishnamurthy, R. \& Yauch, C. A. (2007). Leagile manufacturing: a proposed corporate infrastructure. International Journal of Operations and Production Management, 27(6), 588-604.

Qi, Y., Boyer, K. K. \& Zhao, X. (2009). Supply chain strategy, product characteristics, and performance impact: evidence from Chinese manufacturers. Decision Sciences 40(4), 667-696. 
Mason-Jones, R., Naylor, J. B. \& Towill, D.R. (2000). Lean, Agile or Leagile? Matching Your Supply Chain to the Marketplace. International Journal of Production Research, 38(17), 4061-4070.

Rietze, S. M. (2006). Case Studies of Postponement in the Supply Chain. MSc dissertation. Massachusetts Institute of Technology.

Simchi-Levi, D., Kaminsky, P. \& Simchi-Levi, E. (2008). Designing and managing the supply chain: concepts, strategies, and case studies. Boston: McGraw-Hill.

Stavrulaki, E. \& Davis, M. (2010). Aligning products with supply chain processes and strategy. The International Journal of Logistics Management, 21(1), 127-151.

Swiecki, B. \& Gerth, R. J. (2008). Collaboration in the Automotive Supply Chain - Realising the Full Potential of a Powerful Tool. USA: Centre for Automotive Research.

Świerczek, A. (2010). The relationships between postponement strategies and manufacturing performance in supply chains: an industrial perspective. Log Forum 6, 3, 4. Available at: http://www.logforum.net/vol6/issue3/no4 (accessed on 5 January 2011).

Taylor, D. A. (2004). Supply chains: A manager's guide. USA: Pearson Education.

Vinodh, S., Sundararaj, G. \& Devadasan, S. R. (2009). Total agile design system model via literature exploration. Industrial management and data system, 109(4), 570-588.

Webster, S. (2008). Principles and tools for supply chain management. USA: McGraw-Hill.

Wikner, J. \& Rudberg, M. (2005). Integrating production and engineering perspectives on the customer order decoupling point. International Journal of Operations and Production Management, 25(7), 623-641.

Yang, B. \& Burns, N. (2003). Implications of postponement for the supply chain. International Journal of Production Research, 41(9), 2075-2090.

Yang, B., Burns, N. D. \& Backhouse, C. J. (2004). Postponement: a review and an integrated framework. International Journal of Operations and Production Management, 24(4), 468-487.

Yeung, J. H., Selen, W., Zhou, D. \& Zhang, M. (2007).Postponement strategy from a supply chain perspective: Cases from China. International Journal of Physical Distribution \& Logistic Management, 37(4), 331356.

Zheng, Y. \& Mesghouni, K. (2011). Using Postponement as a Rescheduling Strategy in the Supply Chain Management under Uncertain Demand Environment. Proceedings of the International MultiConference of Engineers and Computer Scientists, Vol II, IMECS 2011, March 16-18, Hong Kong. 